\title{
SOLIDARITY VALUE IN EXTREME JOB FILM BY LEE BYUNG HUN
}

\author{
Chalimatus Shadiyah, Jannatul Laily Novia Bahari \\ chalimatusshadiyah@gmail.com,noviabahari@gmail.com \\ Program Studi Pendidikan Bahasa Inggris Universitas Islam Lamongan, Sastra Inggris Universitas \\ Negeri Sunan Ampel Saurabaya
}

\begin{abstract}
Based on Korean Film Data, Extreme Job is a Korean action comedy film has become the second best-seller Korean film which is directed by Lee Byung Hun. Not only is the comedian's story interesting, this film also contains solidarity value. The problem in this study is how the representation of solidarity value through Extreme Job film by Lee Byung Hun? To elaborate the problem in depth, this study uses the method of semiotic analysis by Roland Barthes. The aim is to analyse the representation of solidarity value in Extreme Job film. Barthes's semiotic analysis, namely denotative and connotative. Denotation is the first step in system of signification. It explained shortly, densely, and clearly. Connotation is the second step in system of signification. It explained more extensively than denotation because connotation is liberal. On the significance of the first step is cohesion showed by the existence of togetherness on doing something, the persuasion is the result of their solidarity also as a reason in order to buy the chicken restaurant through altruism, and division police's jobs for investigating narcotic consumers to various places where destinated by delivers of chicken with narcotic. On the significance of the second step is cohesion as a solidarity indicated based on main purpose of police, recklessness of altruism that showed solidarity among job partners for make success their mission to chasing the group of narcotic fugitives, and job division sign that showed solidarity among job partners for arresting the group of narcotic fugitives.
\end{abstract}

Keywords: Solidarity, Film

\section{INTRODUCTION}

Solidarity is compactness, togetherness, loyalty, intimate relationships in each individual and group to achieve certain goals. The solidarity felt in group. A figure of sociology, Emile Durkheim said that solidarity implies the fundamental ties between members of a small or large group (Giannakopoulus, 2017). Solidarity is very important because human are social creatures who need others, such as family, friends, and neighbour.

Based on CNN Indonesia, in 2016 the fifth President of Indonesia, Megawati Soekarno Putri said that mutual cooperation is Indonesian culture. She announced that in front of 1307 participants when substituting President Jokowi at World Culture Forum 2016 held in Bali. She summoned to all of participants that mutual cooperation is requisite in relations between communities and nations for a better world future (Taylor, 2016).

In 2017, economic growth of East Java always outperformed national economic growth. It is a realization of the government leadership model that prioritizes community participation with theme Mutual Cooperation Model to Build East Java. The mutual cooperation also shows the existence of solidarity between the government and the community. They are together and support each other in order to achieve a progress in the economic field (Advertorial, 2017).

In 2018, the government of Cimahi had a program for Non-Habitable Homes (Rutilahu). According to the government, the program was carried out cooperatively with help from the government. The Head of the Cimahi City National Unity Office, Totong Solehudin said that mutual cooperation faded along with the times and technological 
sophistication. When the program was conducted, not all of the people helped (Ann, 2018).

The case is as same as the researchers found in the surrounding environment. Some people who are members of an organization often do not attend meetings. It is daily meetings and work program meetings. Reason of not attending the meeting is pursue a personal interests. Human are more emphasize personal importance rather than group importance. It shows the community has become individualistic and mutual cooperation has faded in the globalization era that has been dominated by advanced technology.

In 2019, Febriani and friends, Student Creativity Program from Yogyakarta State University thought that mutual cooperation moved values caused by influence of social change. Those social changes are related to the development of information technology and industry, the high level of community activity so that the mutual cooperation process is replaced by material money. The team won an award after creating work in the form of media can foster interaction and reduce conflicts between those which have been resolved by special communities (Lufityanti, 2019).

In 2020, some of Indonesia citizen have been exposed an epidemical disease, Covid-19 which have mean Corona Virus Disease 19. The virus spread to other people quickly through atmosphere. Therefore, government of Indonesia summoned to citizen to do social distancing by isolate themselves at home autonomously. Although the government has already state the information but it disregarded by citizen (Tim detik.com, 2020). Society are still swarm out of home and doing activity as usually. They do not care the existence of Covid-19 which danger to their health and the health of people who they loved.
Whereas, if they going out and meet or touch other people out will bring virus that estimated Covid-19. Virus have been patched in their body will spread to their family in home that caused a family have been spread the virus then dead. It showed that citizen are lose their solidarity. At conference of press in palace of presidency of Bogor, the seventh President of Indonesia, Joko Widodo said citizen's solidarity is an important capital of social to fight Covid-19 together (Pradipta, 2020). It means, citizen must have solidarity to restrain the spread of Covid-19.

To growing up and increase solidarity in society, the researcher recommended a film that contains solidarity values, Extreme Job movie. Based on Korean Film Data, that The Extreme $J o b$ film is an action comedy film which is the second best-seller Korean film of all time. This film has attracted the attention of up to 16.2 million viewers with revenues of US $\$ 120$ million. This film tells the story of a group of police teams who dared to change their profession into temporary fried chicken sellers. They did this for the sake of success in capturing fugitives of drug traffickers.

Although the action comedy film, it turns out tucked into the value of solidarity behind the funny action of the main cast. Solidarity value can be examined through the signs on every scene. In life, humans always need signs to represent a thing and an activity carried out by everyone. These signs can be identified as a knowledge which is studying objects and events (Wibowo, 2013). In the Extreme Job film there are screenshot of scenes and spoken languages like dialogues that shows signs of solidarity.

Solidarity values in the film is seems real and lively, but everyone have different opinion when they look the actors do something on the film. Furthermore, 
viewers also have other opinion based on myth or story which contain interpretation about society. The other opinions and myths can analyze using semiotic by Rolland Barthes. In his theory, Barthes analyzed and founded sign through myth and people opinions beside sign was seems live and commonly. This research will analyze the signs of solidarity using semiotic analysis to determine the representation of signs of solidarity in the movie depend on screenshot of scenes and dialogues.

Semiotics is a study of signs. Signs illustrated through icon, index, symbol as well as symbol of combination of words. Through film, the reader will

\section{METHOD}

Research method presents the methodology which is used by the researcher to analyse data. This is very important to do a research, the researcher needs to apply the correct method. This study uses qualitative method with descriptive design which describes solidarity value in Extreme Job film by Lee Byung Hun using semiotic analysis by Roland Barthes.

Research method in Barthes's perspective of semiotic is collecting lexia, choosing code in lexia, searching relation in lexias, unite the codes, and concluding the codes (2017: 135). He used it to analyze structural narrative text such as book but film also can analysed using Barthes's method through analyze the dialogue as the text. Dialogue at every scene in Extreme Job film contains language as a lexia which have hidden meaning and concluded to codes suggested by Barthes. Then the conclusion related to the activities structured at every scene in the film. The dialogue and scenes can be meaning as an $\mathrm{E}$ for expression in Barthes's system of signification. So, both represented as a $\mathrm{C}$ for content.

By this research, researcher vindicated that Barthes's theory can used understanding signs of solidarity through scenes and dialogue with the semiotic analysis method. At previous studies, semiotic is used to analyze moral value, meaning of determination, and meaning of time in three different films while this research analyzed solidarity value in film also. Therefore, this research selected with the title "Solidarity Value in "Extreme Job" Film by Lee Byung Hun Using Semiotic Analysis". This research can also foster the solidarity of every person who is incorporated in each group or team in various countries, especially Indonesia.

to analyze a film that is not structural narrative text. Additionally, Barthes said in Elements of Semiology, purpose of semiotic is rebuild the function of system of signification in language and process of activity structured. The advantage of system of signification by Barthes's is understand the cultural meaning based on personal experience.

The source of data is the Extreme $J o b$ film by Lee Byung Hun which aired in cinema on January $23^{\text {rd }}$, 2019. The film lasts 111 minutes. Based on Korean Film Data, that the Extreme Job film is an action comedy film which is the second best-seller Korean film of all time. This study is limited to images related to the value of solidarity in film, including audio and visual.

In this research, the data is screenshot of scenes and spoken languages like dialogues of Extreme Job film. Screenshot of scenes and spoken languages become data analysis in this research because they showed activities, behaviours and implied conversations related to solidarity value. The screenshot of scenes connected with dialogues as spoken languages to confirm existence of solidarity value in the Extreme Job film. 
Researcher studied about semiotic analysis by Roland Barthes to find solidarity value in Extreme Job film theoretically. Then researcher studied connotation and denotation deeply for more understanding the theory. Researcher observed the screenshot of scenes and dialogues in Extreme Job film using semiotic analysis by Roland Barthes especially connotation and denotation. Finally researcher found and represent the solidarity value in Extreme Job film.

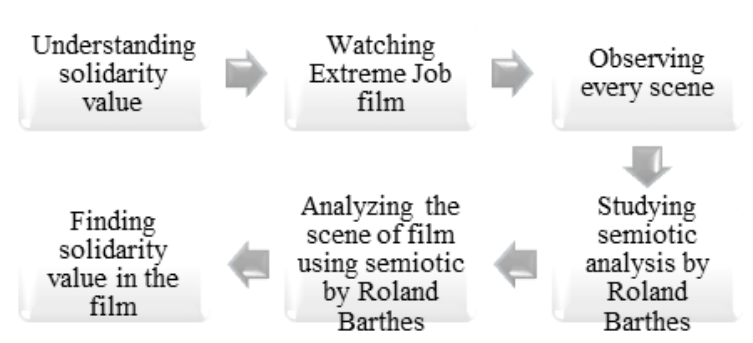

\section{DISCUSSION}

The decrease of Indonesian society's solidarity cause compactness to do activity together is decrease too. Moreover the existence of Covid-19 now, society should be more caring each other, such as care in food, economy, and health especially. Recently, society difficult to keep their health because the health of someone influenced by the health of other people.

To keep health in this pandemic era, we recommended to do social distancing. According to Guide of Quick Medical and Society Health Handling for Covid-19 in Indonesia, social distancing is limitation of society's activity in an area (Jati, 2020). In social distancing, society should be cooperative for doing everything recommended by government, such as working, praying, school from home, and other activities which done in home.

Although that recommended by government but society still go out of home and doing activity there, such as working, praying, shopping, meet up friend, and other. Whereas, out of home viruses are spread more through air and physic touching. When someone doing physic touching out of home with people or things, virus will patch at body or clothes that worn easily. Then, when someone go home, they will spread the virus to their family who stay in home unintentionally.

To break off the spread of Covid19, everyone need to increase caring each other. With the existence of care, solidarity each other will created because solidarity is Very important in society group. In this research, researcher found three values of solidarity in Extreme Job film, they are cohesion, altruism, and division of duty. To explain more the sign of solidarity and rebuild a system of signification, researcher explained the finding and discussion about solidarity value in Extreme Job film. There are two sign there, screenshot of scene and dialogue as a signifier and the representation as a signified. The conclusion of signifier and signified became a denotative sign then developed more became a connotative sign.

\section{Cohesion}

At timeline 00:02:01 - 00:05:09, Detective Jang and her job partner observing a flat, a place where four 
fugitives or narcotic consumer gambling. Detective Jang and Captain Go standing guard out of window using window cleaner's cradle. While Detective Young Ho and Detective Jae Hoon standing guard out of their flat door.

When police arrived in a flat, three of them look so calm and do not worry but one of them look very worry and hurry up to go out. When a fugitive go out, police surrounded him but it is failed. Captain Go, a leader of police team in narcotic sector is fall down from the cradle that cause an accident and made him can not chasing the fugitive. Detective Jang tried to help him but Captain Go reject it and asked her to chasing the fugitive in order to do not go away.

From the flat, Detective Young Ho and Detective Jae Hoon running quickly also to follow Detective Jang for chasing the fugitive. At the scene, Detective Jang is the first to chasing the fugitive because she observed the fugitives through window out of flat. While Detective Young Ho and Detective Jae Hoon are late more than her because they observed the fugitives in a flat that made them go down through lift of the flat which disposed so long. Although the distance among them and Detective Jang is so far enough but they tried to running quickly and arresting the fugitive. It have done by the police who want to show their solidarity in finishing a case because they often failed. It means although they do not be look together but they have a similar purpose.

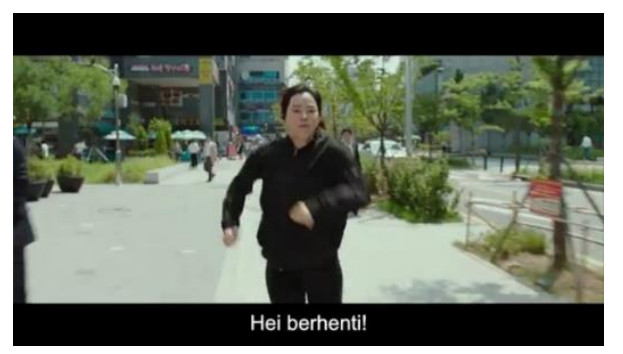

Picture 1. Detective Jang is chasing a fugitive

At timeline 00:04:57 - 00:05:47, can be seen a scene polices was running quickly for chasing a fugitive and cried as a signifier. While signified of the scene is picture 1 showed setting of place on sidewalk. The picture indicated Detective Jang was running for chasing the fugitive.

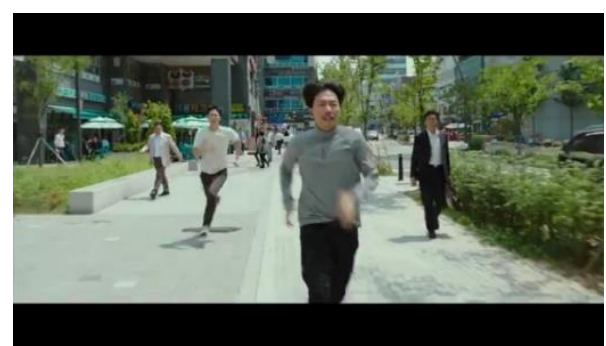

Picture 2. Detective Young Ho and Detective Jae Hoon running toward Detective Jang for chasing the fugitive

Then picture 2 showed similar place with the picture 1, on sidewalk. The picture indicated two Detective Jang's partners, Detective Young Ho and
Detective Jae Hoon was running to follow her for arresting the fugitive.

Denotatively, the scene indicated a police woman followed by two her 
partners who have similar profession with her, police. Her partners does not let a police woman to chasing the fugitive by herself because the fugitive who chased by them is not only police woman's duty but also two other police's duty. At the scene, there is no dialogue among actors because the main point is polices focus on chasing the fugitive who they will arrest. The dialogue at the scene is only "야, 그만!" ("Hey, stop!"), Detective Jang said for warning the fugitive in order to stop and give up himself to polices because of his mistake of consumed narcotic.

Connotatively, at the scene implied a cohesion that showed solidarity among job partners to get the similar purpose, chasing and arresting the fugitive. At the scene, there are three polices who chasing the fugitive. Whereas, actually there are five polices in their team, narcotic division. The three polices must be responsible to arrest the fugitive because the leader of their team, Captain Go have an accident when he was doing a trap the fugitive. Therefore, the leader could not chase the fugitive and instructed partners for chasing him. While the leader try to get up from the accident by himself. It caused as a police in team, arresting the fugitive is impersonal importance which more important than personal.

Detective Ma, the other partner chose to chase the fugitive by grazing him using motorcycle in order to more quickly for arresting him. Commonly, compactness showed or indicated by the existence of togetherness on doing something. While the scene did not showed togetherness among job partners. The sign of compactness as a solidarity indicated based on main purpose of police. Therefore, although the police does not seem together, but the police team have a similar purpose for arresting the fugitive.

\section{Altruism}

At timeline 00:25:15 - 00:25:59, can be seen Detective Jang, Detective Young Ho, Detective Jae Hoon, and Detective Ma doing some ignorance to the restaurant owner for prevent him to sell the chicken restaurant to other people. They persuaded the restaurant owner in order to be patient for someday to sell the restaurant to other buyer. The restaurant owner did not believe with they told about because they does not have money to buy the chicken restaurant. To make the restaurant owner believe them, Detective Young Ho lied the restaurant owner that they are a family who have a business.

Then, Captain Go arrived in the restaurant while bring some money to buy it. The restaurant owner agreed to sell it to them and give a signatory on an agreement letter within official stamp. After that, the restaurant owner believed they are a family and hoped their business will be success. The polices who guised as a family felt roomy because they attain to persuade and get a place for make success their mission.

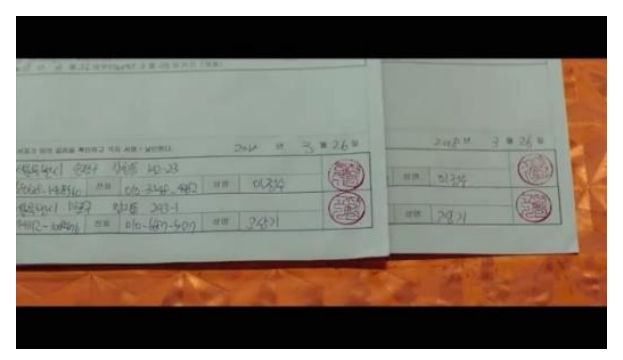

Picture 3. Agreement Letter of Restaurant Sale 
At timeline 00:26:00 - 00:26:36, can be seen a scene police team was doing a signatory at letter and an agreement of ownership movement of restaurant which they bought from the old owner as a signifier. While signified of the scene is picture 3 showed an ownership letter of the restaurant within official stamp.

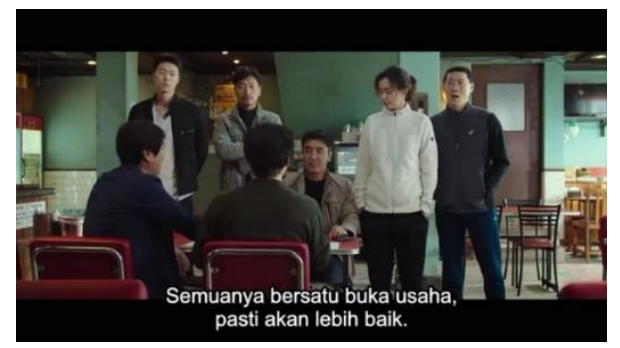

Picture 4. The Owner of Restaurant and The Polices were Discussing

The condition above showed the setting of place in a restaurant. The picture indicated the owner of restaurant and a police team was discussing about purchasing the restaurant and ownership movement.

Denotatively, the scene showed polices were doing a negotiation with the restaurant owner for buying the restaurant and made it became a basecamp. The basecamp used by them for monitoring activities of the group of narcotic fugitives around their station which located exactly opposite the restaurant. To cover their profession as police, they guised as a family who wanted to do a business in Suwon area. Suddenly, the owner of the restaurant told to the police that his restaurant always quiet and nobody come there for buying chicken. Therefore, the owner agreed for selling his restaurant to the police.

In dialogue when they were doing negotiation, the police said some untruth to trick the restaurant owner. First, Detective Young Ho said that they are a family then explained one by one. He saids, "네, 맞아요. 이 둘이 형제, 이 둘이 부부입니다" ("Yes, right. The both are sibling and the both are couple"). His dialogue indicated his initiative to trick the restaurant owner in order to sell the restaurant to the police. Commonly, untruth is a negative thing which is should not to do but untruth can do if it contains positive tactic. Untruth which is done by them is an untruth contains positive tactic because they lied to get the restaurant as their basecamp for observing and arresting fugitives in order the spread of narcotic will not become more expand.

When Captain Go was holding Detective Jang's arm and said that he is Detective Jang's husband, the restaurant owner felt doubt almost that they lied to him because Detective Young Ho said Detective $\mathrm{Ma}$ and Detective Jang is a couple before. By their solidarity, Captain Go got an idea easily to lying him again and said that he is only Detective Jang's former husband. It can be seen on Captain Go's dialogue to the restaurant owner, “전남편” (“I am her former husband”) which is spoken by him with whispering expression that indicated he talking about secret. The secret means Captain Go's persuasion to the restaurant owner in order to believe and can trick him.

The persuasion is the result of their solidarity also as a reason in order to buy the chicken restaurant through change the identity. As a team who has a high solidarity, other partner also expressed their happiness like a harmonious family which have conformity although they have been separated. The restaurant owner have been persuaded again by their action in guise. 
After they bought the restaurant to be basecamp of observing fugitive, they also sell fried chicken there because many people came there to buy fried chicken. First, they said that the fried chicken is sold out but they can not to say similar thing to customers who come there everyday. Fortunately, Detective Ma have been ever worked in chicken restaurant before until they chose to sell fried chicken in their restaurant. Through change their identity became fried chicken seller, they not be seen as a police who were observing fugitives.

Connotatively, at the scene implied recklessness of altruism that showed solidarity among job partners for make success their mission to chasing the group of narcotic fugitives. As a police commonly, difficult for them to buy a chicken restaurant and change their identity become a chicken seller. Moreover, comparison between a profession of police and a chicken seller are very different. A profession of police gotten through several steps in special education. While became a chicken seller could done without assail a special education but needed super financial.

Additionally, usually they who doing a profession as a police must undertake a risk to doing a job of chicken seller. Usually, police have duty to setting up traffic, observing cases, until arresting rascal and fugitive. While chicken seller doing a job such as shopping some necessary of kitchen, cooking chicken, serving customers, and many other.
Therefore, the police changing their profession willingly while contend the narcotic case.

\section{Job Division}

At timeline 01:11:21 - 01:18:15, Captain Go and their job partners knew that at several branch of their restaurant smuggled a narcotic in a fried chicken box. It made society thought that their fried chicken business is a bad one. One day, Captain Go came to an office which is cooperated with their chicken restaurant. Captain Go admonished the official because he was negligent and careless in controlling the branch of their restaurant. Captain Go and their partners does not believed the official and chose to observing the case by themselves.

They discussed and divided jobs in order to the observation have been done soon. Captain Go asked Detective Jae Hoon to be the chef of their restaurant, Detective Young Ho to observing chicken order at the branch of their restaurant, Detective Ma to be leader of team, and Detective Jang to be manager of the restaurant. This job division is the first in observation of narcotic consumer. This job division is also the existence of solidarity among job partner in problem solving. After the first job division, police divided jobs to the second job division which is more specific. This second job division have been done by them to observing places and body condition of narcotic consumer clearly.

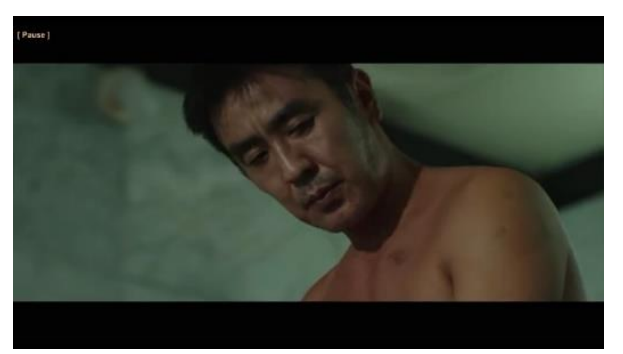

Picture 5. Captain Go looking at Bruises on the Customer's Body 
At timeline 01:15:31 - 01:18:15, can be seen a scene polices divide their jobs for investigating narcotic consumers to various places as a signifier. While signified of those scenes is picture 5 showed setting of place in spa. The picture showed Captain Go is chest off indicated that he guised as a brushman in order to can see the body condition of narcotic consumer such a bruise.

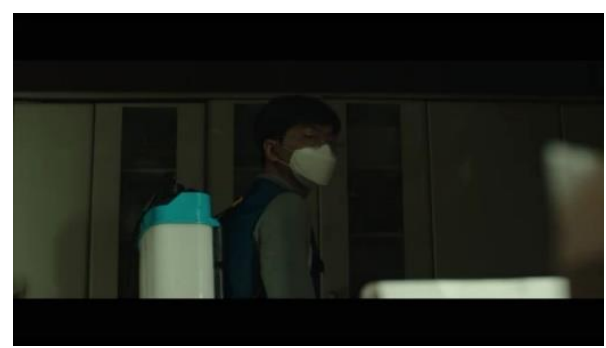

Picture 6. Detective Young Ho Observing the Home to Find Evidence

Then picture 6 showed setting of place in a house. The picture showed Detective Young Ho wore a mask and brought disinfectant tube. The condition indicated he guised as a disinfectant sprayman to narcotic consumer's house in order to can looking for sign of narcotic package around.

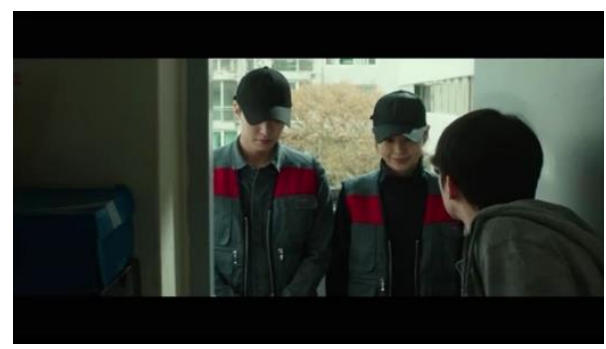

Picture 7. Detective Jang and Detective Jae Hoon Guised as Public Service Official

While picture 7 showed setting of place in a house. The picture indicated Detective Jang and Detective Jae Hoon wore a false waistcoat of a company. That indicated both of them guised as public service official who doing an observation to narcotic consumer's house in order to can looking for signs that home owner is a real consumer.

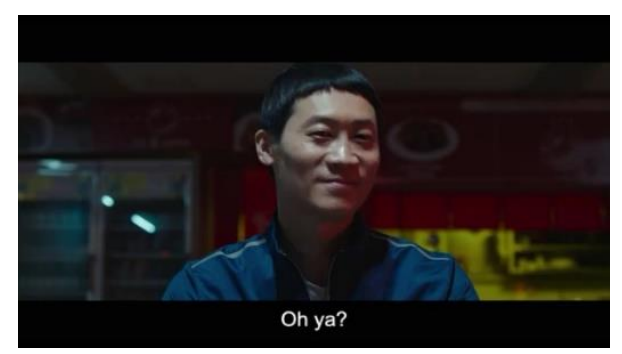

Picture 8. Detective Ma have a Conversation with his Versus

Picture 8 showed setting of place in chicken restaurant which supplying narcotic. The picture indicated Detective Ma guised as a gambler and talking with his versus in order to get information about narcotic distributor.
Denotatively, scenes showed polices divide their jobs for investigating narcotic consumers to various places where destinated by delivers of chicken with narcotic. Polices divide their jobs to make the jobs done soon for arresting 
fugitives. If they does not divide their jobs, so they need long time for arresting fugitives. They divide their jobs to various places where chicken delivered through guised became a brushman, disinfectant sprayman, public service official, until a gambler. At places where they guised, they done jobs to observe and investigate the health of narcotic consumer and situation around.

In spa, Captain Go guised as a brushman to brushing the body of customer. Captain Go saw some bruises on the customer's body there that indicated he consumed narcotic. Detektif Young Ho guised as a disinfectant sprayman to narcotic consumer's house. He saw home owner is seems not health, she trudge and weak, then he observed rooms there and found several packages of narcotic around that indicated the homeowner is a narcotic consumer.

Detektif Jae Hoon dan Detektif Jang guised as public service official. They observed rooms there and found several packages of narcotic around that indicated the homeowner is a narcotic consumer. While Detektif Ma guised as a gambler in a chicken restaurant where supplying narcotic. He talking with his versus then provoked them who also selling chicken with narcotic in order to talking about the narcotic distributor. When they start to talking about the narcotic distributor indicated that they knew about the narcotic distributor until Detective $\mathrm{Ma}$ got information clearly.

In their dialogue, Detective $\mathrm{Ma}$ said, "누구한테 들었니?” ("Who did you hear that from?". His dialogue indicated his curiosity to get an information about narcotic distributor from his versus. He expressed his curiosity calmly to blear his versus in order they feel not suspicious to him. He expressed like he did not know anything about spread of narcotic. Detective Ma said like that to do a job which is discussed with his partners that indicated it is a responsibility of every member on job division.

Connotatively, at those scenes implied job division sign that showed solidarity among job partners for arresting the group of narcotic fugitives. To done the job soon, they had initiative to divide their job. They divide the job to each their member to various places. To do the jobs, police need confidence, braveness, and be responsible.

Police is human usually who have confidence differently. The level of confidence can influence their work in done the job. Some of people who joined police squad felt more confident than before. But, other still felt inferior or not confident to do job in front of society. It caused by something, such as shyness, reluctance, and anxiety or fear. At scenes in the "Extreme Job" movie indicated that polices very confident and enthusiastic when they does observation to various places although by oneself. The scenes also did not showed the existence of polices doubt to done their jobs.

Not confidence makes polices worry to what will they do in job circle. Some of polices worry and fear to event which threaten them in future. They worry and fear to do a mistake and failed to do a job. Moreover, if they do an observation lonely. Commonly, police who does a job lonely felt more worry than together with their job partner. They who do a job lonely felt confuse to what will they do in job because there is not partner to do mind exchange. But, at the scenes showed that polices does not felt worry, confuse, and fear although they done observation and investigation lonely.

Worry felt by people commonly when they do a job lonely instead growing up careless for their job. Sometime, lazy police who do a job lonely with simple and trivial job instead did not care their responsibility as a job gave by the leader. It caused by they does not want to take a risk means they keep themselves from the 
leader warn. But, at the scenes showed that polices responsible to their job because they make solidarity more important in their team.

In a research, majority of cadet had low worry when they faced job circle. Such in this movie showed that polices had high confidence. The confidence can lower the worry and increase braveness until make them became responsible police to their job. By the solidarity value above, hoped can grow and increase solidarity each other in life as group. Indonesia known as a country that have friendly society means they caring each other and inclined want to recognise and need a friend. In this case, people who knew each other need to grow and increase solidarity in order to be unity or compact group for face a problem until the problem could be done together.

\section{CONCLUSION}

Researcher found three things which contain solidarity value in the "Extreme

\section{REFERENCES}

Advertorial. (2017, May 15 $5^{\text {th }}$ ). Ngopi Bareng Gus Ipul Gotong Royong. Retrieved February $18^{\text {th }} ， 2020$, https://m.detik.com/news/kolom/d3501331/gotong-royong.

Annonimous. (2004). Ensiklopedi Nasional Indonesia. Jakarta: PT. Delta Pamungkas (Jilid 15 SF - SY).

Annonimous. (2018, January $28^{\text {th }}$ ). Memudarnya Kebiasaan Gotong Royong. Retrieved February $18^{\text {th }}$, 2020 ,

https://www.google.com/amp/s/lima waktu.id/amp/news/memudarnyakebiasaangotong-royong.

Barthes, R. (1964). Elements of Semiology. Paris: Editions du Seuil.
Job" film, cohesion, altruism, and job division. Cohesion as a compactness is an activity that do together but researcher found compactness is an activity that do to get a similar purpose although do not to do together in this film.

Commonly, for police, change of identity is a difficult thing to do because many things must be priority but change of identity in this film is an important thing because polices priority their job for final a crime. Actually, job division in a job became a common thing in society. Sometimes, some of people felt jealous, do not confident, and worry to receive a job division which is unfit with their passion. In this film, job division done by polices confidently, professionally, and without jealous and worry to fail. The existence of the signs also can stimulate growth of solidarity each other. The three things in "Extreme Job" film should growing in self in order to grow and increase the solidarity too.

Barthes, R. (1973). S/Z. Paris: Editions du Seuil.

Batson, C. D. (2011). Altruism in Humans. New York: Oxford University Press, Inc.

Budiati, A. C. (2009). Sosiologi Kontekstual: Untuk SMA \& MA Kelas X. Jakarta: Pusat Perbukuan, Departemen Pendidikan Nasional.

Durkheim, E. (2005). Suicide: A Study in Sociology. Taylor \& Francis eLibrary.

Forsyth, D. R. (2019). Group Dynamics: Seventh Edition. Boston: Cengage Learning, Inc.

Giannakopoulos, A. 2017. Solidarity in the European Union: Challenges and 
Perspectives. Tel Aviv University: The S. Daniel Abraham Center.

Halik, A. (2013). Komunikasi Massa. Makassar: Alauddin University Press.

Ilmi, M. N. (2017). Makna "Waktu" Dalam Film In Time. Skripsi. Makassar: Fakultas Ilmu Sosial dan Ilmu Politik. Universitas Hasanudin

Jati, A. (2020, March 26 $\left.{ }^{\text {th }}\right)$. Beda Makna Social Distancing dan Physical Distancing. Retrieved June $15^{\text {th }}$, 2020,

https://www.liputan6.com/bola/read/ 4211243/beda-makna-socialdistancing-dan-physical-distancing

Lantowa, J., Marahayu, N. M., Khairussibyan, M. (2017). Semiotika: Teori, Metode, dan Penerapannya dalam Penelitian Sastra. Yogyakarta: Penerbit Deepublish

Lufityanti, G. (2019, November $\left.19^{\text {th }}\right)$. Kaji Gotong Royong yang Semakin Pudar, Mahasiswa UNY Raih Perungguh dalam PIMNAS. Retrieved February $18^{\text {th }}, 2020$, https://jogja.tribunnews.com/2019/1 1/15/kaji-gotong-royong-yangsemakin-pudar-mahasiswa-uny-raihperunggu-dalam-pimnas

Nugroho, D. (2019). Pesan Moral Film Yowis Ben. Skripsi. Surabaya: Fakultas Dakwah dan Komunikasi. Universitas Islam Negeri Surabaya

Pradipta, B. (2020, March $\left.16^{\text {th }}\right)$. Pernyataan Lengkap Jokowi Soal Lockdown, Kepala Daerah Diwantiwanti, hingga Pesan Solidaritas. Retrieved April 2 $2^{\text {nd }}, \quad 2020$, https://m.tribunnews.com/amp/coron a/2020/03/16/pernyataan-lengkap- jokowi-soal-lockdown-kepala-

daerah-diwanti-wanti-hingga-pesansolidaritas?page $=4$

Prasetyaningsih, N. (2016). Representasi Makna Tekad Dalam Film Kahaani. Skripsi. Serang: Fakultas Ilmu Sosial dan ilmu Politik. Universitas Sultan Ageng Tirtayasa Serang

Priherdityo, E. (2019, February $\left.22^{\text {nd }}\right)$. Ulasan Film: 'Extreme Job'. Retrieved March $1^{\text {st }}$ 2020, https://m.cnnindonesia.com/hiburan/ 20190221220906-220371667/ulasan-film-extreme-job

Rachmat, N. A. P., Rusmawati, D. (2018). On literature's usefulness: Hubungan Antara Regulasi Diri dengan Kecemasan Menghadapi Dunia Kerja Pada Taruna Akademi Kepolisian Semarang. Semarang: Universitas Diponegoro.

Taylor, G. S. (2016, October $\left.14^{\text {th }}\right)$. Megawati Perkenalkan Budaya Gotong Royong ke Dunia. Retrieved February $18^{\text {th }}, \quad 2020$, https://m.cnnindonesia.com/nasional /20161014101856-20-

165455/megawatiperkenalkanbudaya-gotong-royong-ke-dunia

Tim. (2020). Pemerintah Prihatin Banyak Pelanggar Social Distancing, Anak Muda Sering Abai. Detik.com (https://m.detik.com/news/berita/d4955476/pemerintah-prihatinbanyak-pelanggar-social-distancinganak-muda-sering-abai) Accessed on June $16^{\text {th }}, 2020$

Wibowo, I. S. W. (2013). Semiotika Komunikasi: Aplikasi Praktis Bagi Penelitian dan Skripsi Komunikasi. Jakarta: Mitra Wacana Media. 
Wijayanti, D., Kawedhar, W. H. Sosiologi: Untuk SMA/MA Kelas X Semester 1. Intan Pariwara.

https://id.m.wikipedia.org/wiki/Extreme_J ob Accessed on February $29^{\text {th }}, 2020$ https://www.kanalinfo.web.id/pengertiandata-primer-dan-data-sekunder Accessed on March 1 ${ }^{\text {st }}, 2020$

https://www38.zippyshare.com/v/rIoaeSH 3/file.html Accessed on October $10^{\text {th }}, 2019$ 